Research Article

\title{
Seismic Performance of Lightweight Concrete Structures
}

\author{
Swamy Nadh Vandanapu $(\mathbb{D}$ and Muthumani Krishnamurthy \\ VIT University, Chennai, India \\ Correspondence should be addressed to Swamy Nadh Vandanapu; swamynadh.2016@vitstudent.ac.in
}

Received 16 June 2017; Revised 18 September 2017; Accepted 18 October 2017; Published 6 February 2018

Academic Editor: Pier Paolo Rossi

Copyright (c) 2018 Swamy Nadh Vandanapu and Muthumani Krishnamurthy. This is an open access article distributed under the Creative Commons Attribution License, which permits unrestricted use, distribution, and reproduction in any medium, provided the original work is properly cited.

\begin{abstract}
Concrete structures are prone to earthquake due to mass of the structures. The primary use of structural lightweight concrete (SLWC) is to reduce the dead load of a concrete structure, which allows the structural designer to reduce the size of the structural members like beam, column, and footings which results in reduction of earthquake forces on the structure. This paper attempts to predict the seismic response of a six-storied reinforced concrete frame with the use of lightweight concrete. A well-designed sixstorey example is taken for study. The structure is modelled with standard software, and analysis is carried out with normal weight and lightweight concrete. Bending moments and shear forces are considered for both NWC and LWC, and it is observed that bending moments and shear forces are reduced to 15 and 20 percent, respectively, in LWC. The density difference observed was $28 \%$ lower when compared NWC to LWC. Assuming that the section and reinforcements are not revised due to use of LWC, one can expect large margin over and above MCE (maximum considered earthquake; IS 1893-2016), which is a desirable seismic resistance feature in important structures.
\end{abstract}

\section{Introduction}

Lightweight concrete has low density and is adaptable for construction of buildings in low-seismic zones. Structural seismic responses are based on mass of the structure or dead weight of the structure; the selection of materials to maintain the dead weight low should be adopted. Concrete is used to construct any structure; the ingredients of the concrete are cement, sand, and aggregates. $70 \%$ of the concrete is composed of aggregates (fine and coarse aggregates). Selection of such aggregates has been investigated by a number of researchers for the very long time and stated the approximate compostion of materials for structural lightweight concrete $[1,2]$. There are so many lightweight aggregates available in the market; one has to choose which is less porous, less dense, and economical and performs better.

The first modern use of high-performance lightweight concrete is when a lightweight concrete ship was built in 1917 to 1920 using $35 \mathrm{MPa}$ concrete. High strength is achieved in lightweight concrete by incorporating various pozzalans with mid-range water reducing admixtures. The concrete structure which houses Bank of America, Corporate Centre, and Charlotte, North Carolina, is a tall building with a height of $265 \mathrm{~m}$ and having sixty storeys. The floor system consists of $117 \mathrm{~mm}$ thick slab supported on a $460 \mathrm{~mm}$ deep beam centred at $3 \mathrm{~m}$. The strength of concrete varied between 43 and $51 \mathrm{MPa}$ while the density of concrete is $1890 \mathrm{~kg} / \mathrm{m}^{3}$. Similar experiences are reported in bridges also; nearly 500 bridges have incorporated lightweight concrete into deck, beams, girders, or piers. They are also increasingly used in prefabricated construction because of easier towing, greater buoyancy, and less expensive for handling. Compressive strength up to $100 \mathrm{MPa}$ with lightweight of $1800 \mathrm{~kg} / \mathrm{m}^{3}$ concrete has been reported. The main aim of using lightweight concrete is to reduce the dead load of a concrete structure, which then allows the structural designer to reduce the size of columns, footings, and other load-bearing elements in the structure.

Alaettin Kilic and Cengiz Duran Atis in 2002 [1] had reported that structural lightweight concrete with basic pumice used as lightweight aggregate with and without admixtures gives compressive strength up to $43 \mathrm{MPa}$ and tensile strength up to $8.9 \mathrm{MPa}$ by the use of silica fumes up to $10 \%$ by weight of cement. The lightweight scoria aggregates 
can be utilized to reduce the earthquake acceleration by producing structural lightweight aggregates.

Ramazan Demirboga and Rustem Gul in 2002 [3] had reported that thermal conductivity of concrete made up of expanded perlite and pumice aggregates with replacement of cement with fly ash and silica fumes with $10 \%, 20 \%$, and $30 \%$ by weight gives good results for thermal conductivity of concrete. Thermal conductivity of concrete is decreased by $43.5 \%$ in expanded perlite aggregates.

\section{Analytical Study}

2.1. Modelling and Material Properties. A six-storied reinforced concrete framed structure is modelled using standard software [6], that is, STAAD PRO (Structural Analysis and Aided Design) [4]. The structural model is shown in Figure 1. Beams and columns are arranged in such a way that each beam is $7.5 \mathrm{~m}$ in length, so the secondary beams are acting at each $2.5 \mathrm{~m}$ length; these secondary beams are maintained to make the structure stable and uniform. The dimensions of the structure in plan is $22.5 \mathrm{~m}$ wide on either side and $30.2 \mathrm{~m}$ tall, and each storey height is different as can be seen from Table 1.

There are two materials used in the model: one represents lightweight concrete and the other is normal weight concrete. The weight densities of each concrete are categorised according to ACI 318 building code requirements for structural concrete (ACI 318-95) and commentary (ACI 318R-95) [5], and "Test Method for Unit Weight of Structural Lightweight Concrete” (ASTM C 567) [7], not exceeding $1800 \mathrm{~kg} / \mathrm{m}^{3}$. In this code, a lightweight concrete without natural sand is termed "all-lightweight concrete," and lightweight concrete in which all of the fine aggregate consists of normal weight sand is termed "sand-lightweight concrete." The density of lightweight concrete used in the model is $1800 \mathrm{~kg} / \mathrm{m}^{3}$, and the density of normal weight concrete is $2500 \mathrm{~kg} / \mathrm{m}^{3}$. Modulus of elasticity of each model is calculated according to ACI 213 [8]. The below expression is meant to be valid for values of density from 1400 to $2480 \mathrm{~kg} / \mathrm{m}^{3}$ :

$$
\begin{aligned}
& E_{c}=43 * 10^{-6} \rho^{1.5} \sqrt{f_{\mathrm{ck}}^{\prime}} \text { lightweight concrete (ACI 318R), } \\
& \left.E_{c}=5000 \sqrt{f_{\mathrm{ck}}} \text { normal weight concrete (IS } 456: 2000\right),
\end{aligned}
$$

where $f_{\mathrm{ck}}^{\prime}$ is the characteristic strength of cylindrical strength; $f_{\mathrm{ck}}$ is the characteristic strength of concrete cube in $\mathrm{MPa}$, where $f_{\mathrm{ck}}^{\prime}$ is 0.8 times of $f_{\mathrm{ck}} ; \rho$ is the density of concrete in $\mathrm{kg} / \mathrm{m}^{3}$; and $E_{c}$ is the modulus of elasticity.

Material selected for both the models is concrete, and the structure is designed according to IS 456:2000 [9]. Some of the material properties were flexural strength of concrete, modulus of elasticity of concrete, and density of steel reinforcement. M30 grade of concrete is used for the study.

2.2. Loads and Load Calculations. Modelling of the structure is done using standard software; the structure is taken from standard book. Loads are taken from the same book and implemented in the design (Table 1). For modelling of LWC

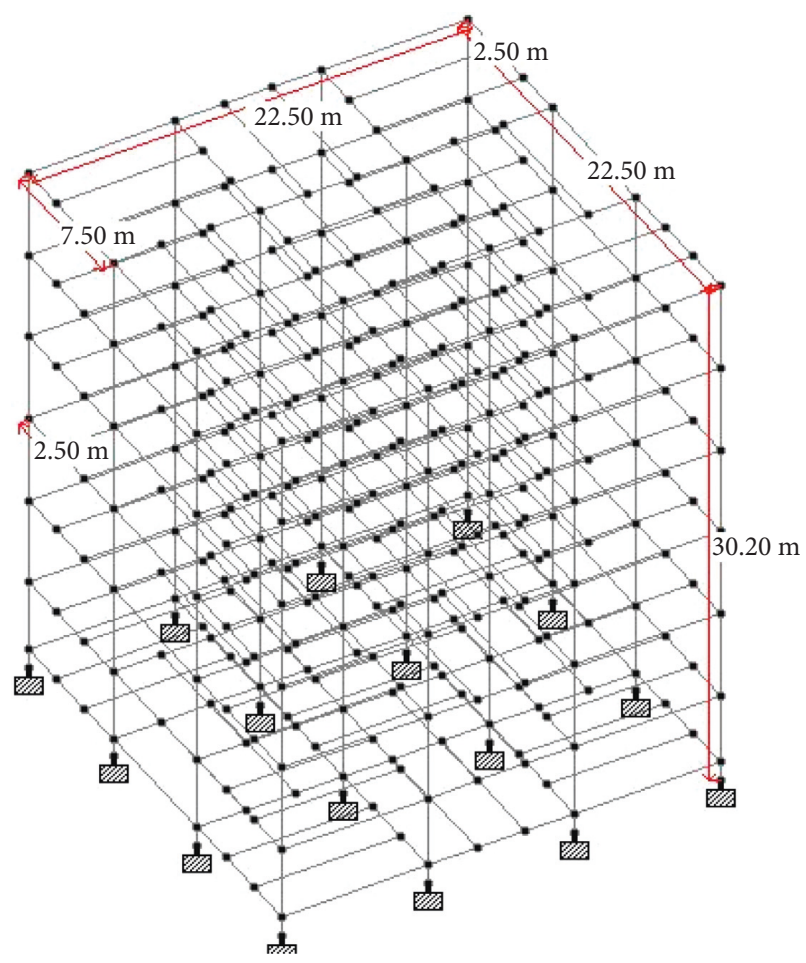

Figure 1: Model of the six-storied building, 3D view.

Table 1: Design data.

\begin{tabular}{lc}
\hline Live load & $4.0 \mathrm{kN} / \mathrm{m}^{2}$ at typical floor \\
& $1.5 \mathrm{kN} / \mathrm{m}^{2}$ on terrace \\
Floor finish & $1.0 \mathrm{kN} / \mathrm{m}^{2}$ \\
Water proofing & $2.0 \mathrm{kN} / \mathrm{m}^{2}$ \\
Location & Vadodara city \\
Depth of foundation & $2.5 \mathrm{~m}$ \\
below ground & Type II, medium as per IS: 1893 \\
Type of soil & Typical floor $5 \mathrm{~m}$, ground floor: $3.4 \mathrm{~m}$ \\
Storey height & GF +5 upper floors \\
Floor & $0.6 \mathrm{~m}$ \\
Plinth level & $230 \mathrm{~mm}$ thick masonry walls \\
Walls &
\end{tabular}

structure and NWC, the densities of each floor are calculated and implemented in the software as given in Tables 2 and 3. Table 2 shows the design data and load acting on each structure. Load combinations are taken from 1893 to 2016 [10] and listed in Table 4, where $\mathrm{X}$ and $\mathrm{Z}$ are lateral orthogonal directions.

\section{Analysis and Results}

3.1. Bending Moment and Shear Force. The structure was analysed for 25 load cases as listed in Table 3. The bending moment and shear forces are compared with all the members from results obtained from the analytical model. The results are presented in Table 4 for selected members as shown in Figure 2 for bending moment of NWC and 
Table 2: Dead loads.

\begin{tabular}{|c|c|c|c|}
\hline Members & Dimensions (mm) & Normal weight density $\left(25 \mathrm{kN} / \mathrm{m}^{3}\right)$ & Lightweight density $\left(18 \mathrm{kN} / \mathrm{m}^{3}\right)$ \\
\hline Columns & $500 * 500$ & $\begin{array}{c}6.3 \mathrm{kN} / \mathrm{m} \text { (for top floor) } \\
9.0 \mathrm{kN} / \mathrm{m} \text { (rest of the floors) }\end{array}$ & $\begin{array}{c}4.5 \mathrm{kN} / \mathrm{m} \text { (for top floor) } \\
6.48 \mathrm{kN} / \mathrm{m} \text { (rest of the floors) }\end{array}$ \\
\hline Beams & $300 * 600$ & $4.5 \mathrm{kN} / \mathrm{m}$ & $3.24 \mathrm{kN} / \mathrm{m}$ \\
\hline Slab & 100 & $2.5 \mathrm{kN} / \mathrm{m}^{2}$ & $1.8 \mathrm{kN} / \mathrm{m}^{2}$ \\
\hline Brick wall & 230 & $\begin{array}{c}4.9 \mathrm{kN} / \mathrm{m}^{2} \\
21.6 \mathrm{kN} / \mathrm{m} \text { (height } 4.4 \mathrm{~m} \text { ) } \\
17.2 \mathrm{kN} / \mathrm{m} \text { (height } 3.5 \mathrm{~m} \text { ) } \\
3.5 \mathrm{kN} / \mathrm{m} \text { (height } 0.7 \text { ) } \\
4.9 \mathrm{kN} / \mathrm{m} \text { (height } 1.0 \text { ) }\end{array}$ & $\begin{array}{c}4.9 \mathrm{kN} / \mathrm{m}^{2} \\
21.6 \mathrm{kN} / \mathrm{m} \text { (height } 4.4 \mathrm{~m} \text { ) } \\
17.2 \mathrm{kN} / \mathrm{m} \text { (height } 3.5 \mathrm{~m} \text { ) } \\
3.5 \mathrm{kN} / \mathrm{m} \text { (height } 0.7 \text { ) } \\
4.9 \mathrm{kN} / \mathrm{m} \text { (height } 1.0 \text { ) }\end{array}$ \\
\hline
\end{tabular}

TABle 3: Load combinations used for design.

\begin{tabular}{lccc}
\hline 1 & $1.5(\mathrm{DL}+\mathrm{EZTP})$ & 14 & $1.5(\mathrm{DL}+\mathrm{IL})$ \\
2 & $1.5(\mathrm{DL}+\mathrm{EZTN})$ & 15 & $1.2(\mathrm{DL}+\mathrm{IL}+\mathrm{EXTP})$ \\
3 & $1.5(\mathrm{DL}-\mathrm{EZTP})$ & 16 & $1.2(\mathrm{DL}+\mathrm{IL}+\mathrm{EXTN})$ \\
4 & $1.5(\mathrm{DL}-\mathrm{EZTN})$ & 17 & $1.2(\mathrm{DL}+\mathrm{IL}-\mathrm{EXTP})$ \\
5 & $0.9 \mathrm{DL}+1.5 \mathrm{EXTP}$ & 18 & $1.2(\mathrm{DL}+\mathrm{IL}-\mathrm{EXTN})$ \\
6 & $0.9 \mathrm{DL}+1.5 \mathrm{EXTN}$ & 19 & $1.2(\mathrm{DL}+\mathrm{IL}+\mathrm{EZTP})$ \\
7 & $0.9 \mathrm{DL}-1.5 \mathrm{EXTP}$ & 20 & $1.2(\mathrm{DL}+\mathrm{IL}+\mathrm{EZTN})$ \\
8 & $0.9 \mathrm{DL}-1.5 \mathrm{EXTN}$ & 21 & $1.2(\mathrm{DL}+\mathrm{IL}-\mathrm{EZTP})$ \\
9 & $0.9 \mathrm{DL}+1.5 \mathrm{EZTN}$ & 22 & $1.2(\mathrm{DL}+\mathrm{IL}-\mathrm{EZTN})$ \\
10 & $0.9 \mathrm{DL}-1.5 \mathrm{EZTP}$ & 23 & $1.5(\mathrm{DL}+\mathrm{EXTP})$ \\
11 & $0.9 \mathrm{DL}-1.5 \mathrm{EZTN}$ & 24 & $1.5(\mathrm{DL}+\mathrm{EXTN})$ \\
12 & $0.9 \mathrm{DL}+1.5 \mathrm{EZTP}$ & 25 & $1.5(\mathrm{DL}-\mathrm{EXTP})$ \\
13 & $1.5(\mathrm{DL}-\mathrm{EXTN})$ & - & - \\
\hline
\end{tabular}

Figure 3 for LWC. The loading cases yielded maximum values of bending moment and shear forces. Figure 2 shows one of the selected beams in the NWC structure which has bending moment of $260 \mathrm{kNm}$ and shear force of $49 \mathrm{kN}$. Figure 3 shows the beam in the LWC structure which had a bending moment of $226 \mathrm{kNm}$ and a shear force of $45 \mathrm{kN}$. The two cases involving normal weight concrete (NWC) with a density of $25 \mathrm{kN} / \mathrm{m}^{3}$ and lightweight concrete (LWC) with a density of $18 \mathrm{kN} / \mathrm{m}^{3}$ are loads to yield different loading conditions as the density of material is different. Though the live load is the same for both the cases, dead load and seismic weights are considerably less as can be seen form Table 2 .

This results in lesser bending moment and shear force in members as can be seen from Table 4 . The variation in bending moment is lower by $22 \%$ and shear force by $18 \%$ for lightweight concrete when compared to normal weight concrete.

3.2. Percentage of Steel. The six-storied structures are designed as per IS 456:2000 [9] and are analysed. Both the structures are having the dead load variation of $28 \%$, and hence, there is a change in bending moments and shear forces in the structures too. Sectional properties of the lightweight structure can be modified as per the obtained bending moment and shear forces. As the design is done in standard software, the reduction in area of steel in lightweight concrete is about $10 \%-12 \%$ as expected. Quantity of steel in normal weight concrete is $1151 \mathrm{kN}$, and in lightweight concrete it is $1014 \mathrm{kN}$.

3.3. Fundamental Natural Period and Seismic Loads. The approximate fundamental natural period of vibration $\left(T_{a}\right)$ in seconds for the moment resisting frame building without brick infill panels may be estimated by empirical expression given by IS 1893-2016. In the present analysis, for calculating the above parameter, standard software is used to find out seismic response and mode shapes of the structure. The natural period calculated by the code and software is verified and mentioned in Table 5. There is no variation of time periods in both the calculations; this is due to no change in the height of the structure. Compressive strength and elastic modulus of lightweight aggregates are given by Ulrik Nilsen et al. [11]. Young's modulus $E$ value shows negligible time periods for LWC than NWC. Considering Clause 6.4 design spectrum in IS 1893-2016, code says the $S_{a} / g$ value can be taken as $1.36 / \mathrm{T}$ where $T_{a}$ is natural time period. The value of $S_{a} / g$ calculated is varied from 0.72 to 1.4 . But as per clause, 7.8.2 of IS 1893-2016 requires to take the highest force $\left(S_{a} / g\right)$ for calculations taken as 1.402 for computation of seismic forces. Table 6 and Figures 4 and 5 show the horizontal loads and base shear values for LWC and NWC for various floor levels in a structure. From Table 6, the forces in LWC building are 14 percent less than the NWC building.

$$
\begin{aligned}
T_{a} & =0.075 h^{0.75} \\
& =0.075 \times(30.5)^{0.75} \\
& =0.97 \mathrm{sec},
\end{aligned}
$$

where " $T_{a}$ " is natural time period and " $h$ " is height of structure in meters.

3.4. Storey Drifts and Displacements of Each Floor. Storey drifts and displacements are calculated as per Clause no. 7.8 of IS 1893:2016. In this clause, dynamic analysis is performed to the structure of both NWC and LWC. The structure is analysed by the response spectrum method; the design base shear (VB) is compared with a base shear (VB) calculated using a fundamental period $T_{a}$ as per Clause no. 7.11.1 of IS 1893 (Part 1): 2016; the storey drift in any storey due to specified design lateral force with partial load factor of 1.0 shall not exceed 0.004 times the storey height; for a typical floor of six, the storey drift allowed is $20 \mathrm{~mm}$. The considered 
TABLE 4: Bending moments and shear force.

\begin{tabular}{|c|c|c|c|c|}
\hline Beam no. & $\begin{array}{l}\text { Bending moment } \\
\text { for LWC }(\mathrm{kNm})\end{array}$ & $\begin{array}{l}\text { Bending moment } \\
\text { for NWC }(\mathrm{kNm})\end{array}$ & $\begin{array}{l}\text { Shear force } \\
\text { for LWC }(\mathrm{kN})\end{array}$ & $\begin{array}{c}\text { Shear force } \\
\text { for NWC }(\mathrm{kN})\end{array}$ \\
\hline 261 (COMB 16) (COMB 18) & $\begin{array}{c}-223 \\
226\end{array}$ & $\begin{array}{c}-258 \\
260\end{array}$ & $\begin{array}{c}79 \\
-45\end{array}$ & $\begin{array}{c}83 \\
-49\end{array}$ \\
\hline 391 (COMB 16) (COMB 18) & $\begin{array}{c}-258 \\
260\end{array}$ & $\begin{array}{c}-322 \\
328\end{array}$ & $\begin{array}{c}83 \\
-49\end{array}$ & $\begin{array}{c}99 \\
-67\end{array}$ \\
\hline $521(\mathrm{COMB} 16)(\mathrm{COMB} 18)$ & $\begin{array}{c}-270 \\
276\end{array}$ & $\begin{array}{c}-313 \\
320\end{array}$ & $\begin{array}{c}84 \\
-58\end{array}$ & $\begin{array}{c}97 \\
-64\end{array}$ \\
\hline 651(COMB 16) (COMB 18) & $\begin{array}{c}-226 \\
231\end{array}$ & $\begin{array}{c}-265 \\
272\end{array}$ & $\begin{array}{c}-46 \\
75\end{array}$ & $\begin{array}{c}-51 \\
86\end{array}$ \\
\hline 781(COMB 16) (COMB 18) & $\begin{array}{c}-159 \\
167\end{array}$ & $\begin{array}{c}-191 \\
201\end{array}$ & $\begin{array}{c}-29 \\
61\end{array}$ & $\begin{array}{c}-32 \\
71\end{array}$ \\
\hline
\end{tabular}
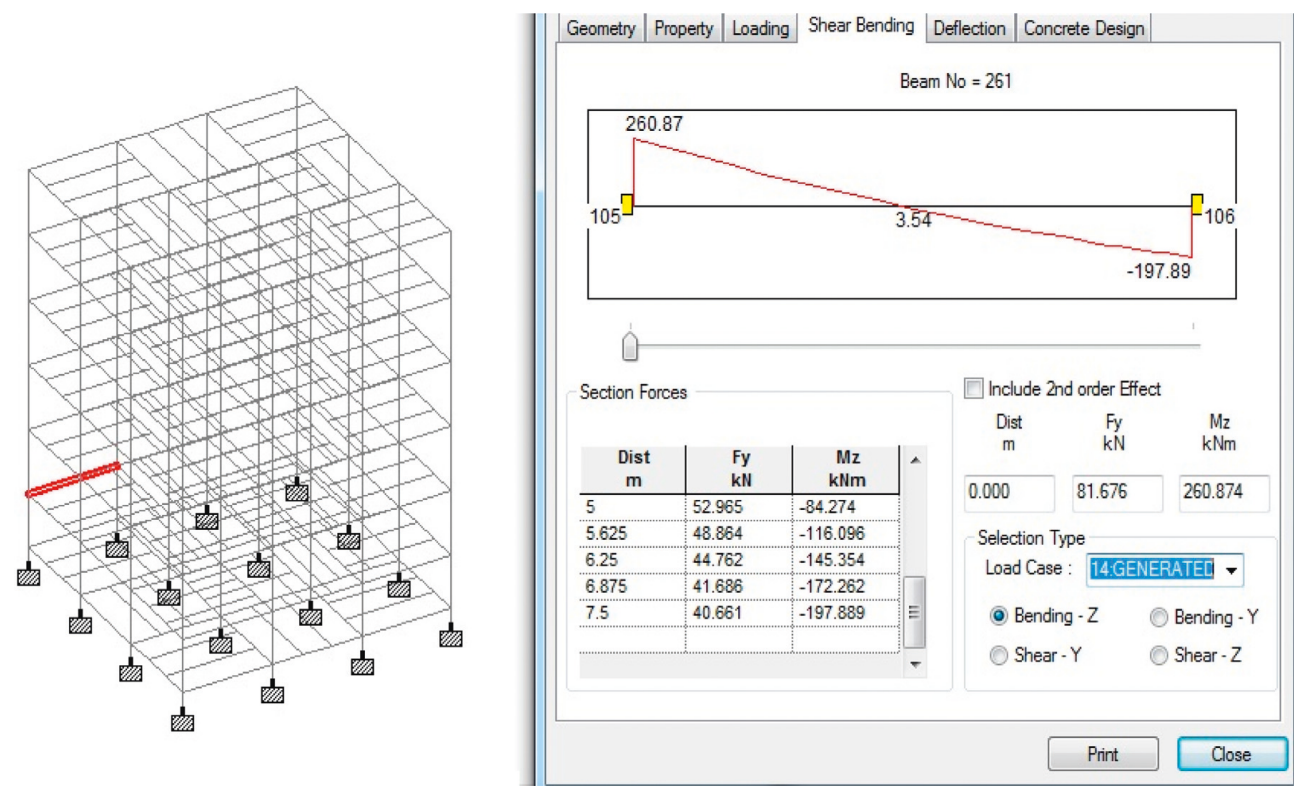

Figure 2: Bending moment for normal weight concrete of the selected member.
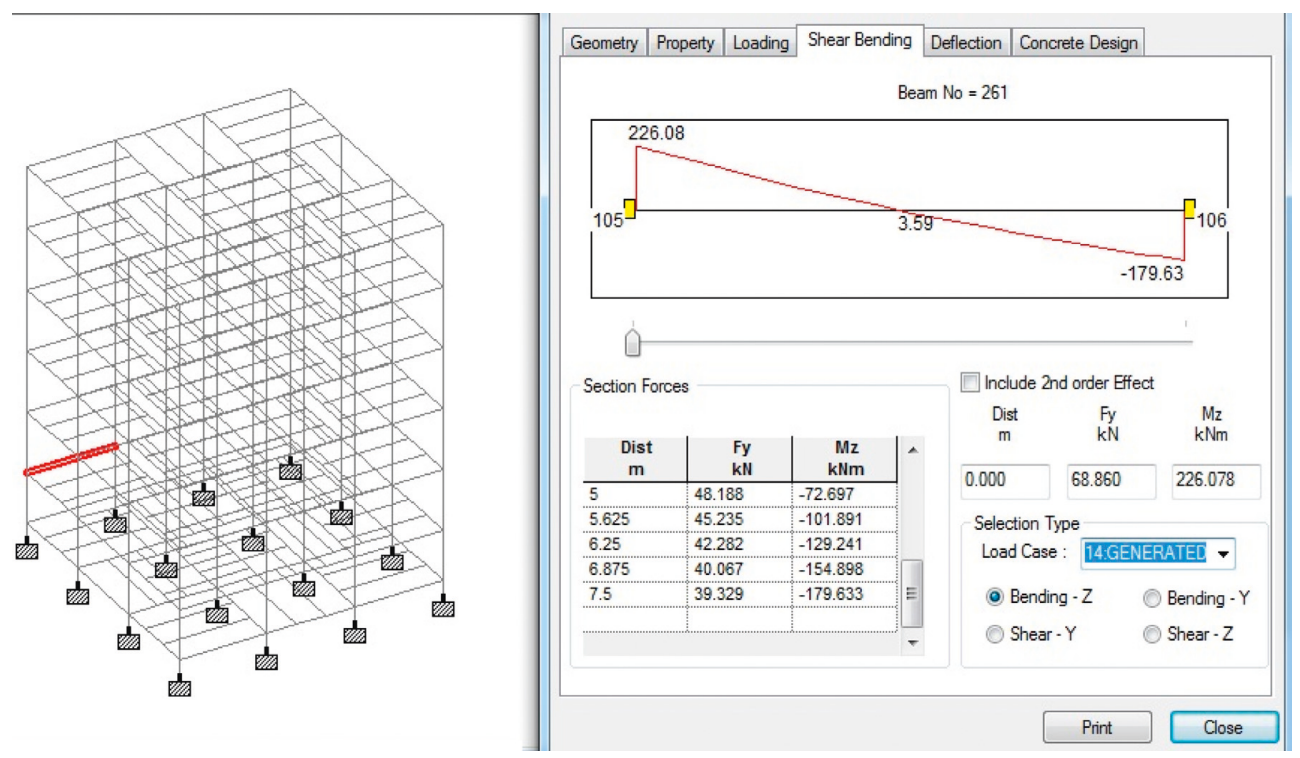

Figure 3: Bending moment for lightweight concrete of the selected member. 
TABle 5: Time periods.

\begin{tabular}{lcc}
\hline $\begin{array}{l}\text { Time } \\
\text { period }\end{array}$ & $\begin{array}{c}\text { Normal weight } \\
\text { concrete }(\mathrm{sec}) \\
\text { IS } 456-2000\end{array}$ & $\begin{array}{c}\text { Lightweight } \\
\text { concrete }(\mathrm{sec}) \\
\text { ECI } 318\end{array}$ \\
\hline$X$ & $27 \mathrm{Gpa}$ & $E=16 \mathrm{Gpa}$ \\
$Y$ & 1.87 & 1.88 \\
$Z$ & 1.85 & 1.86 \\
\hline
\end{tabular}

TABLE 6: Distribution of horizontal loads to different floor levels.

\begin{tabular}{lccccccc}
\hline Storey & $\begin{array}{c}H \\
(\mathrm{~m})\end{array}$ & $\begin{array}{c}W(\mathrm{kN}) \\
\text { NWC }\end{array}$ & $\begin{array}{c}\mathrm{NWN}) \\
\mathrm{NW}\end{array}$ & $\begin{array}{c}V(\mathrm{kN}) \\
\text { NW }\end{array}$ & $\begin{array}{c}W(\mathrm{kN}) \\
\mathrm{LWC}\end{array}$ & $\mathrm{QWN})$ & $V(\mathrm{kN})$ \\
\hline 7 & 30.2 & 5597 & 480 & 480 & 4100 & 366 & 366 \\
6 & 25.2 & 6381 & 380 & 860 & 5611 & 350 & 716 \\
5 & 20.2 & 6381 & 244 & 1140 & 5611 & 224 & 940 \\
4 & 15.2 & 6381 & 138 & 1242 & 5611 & 127 & 1067 \\
3 & 10.2 & 6381 & 62 & 1304 & 5611 & 52 & 1119 \\
2 & 5.2 & 6138 & 16 & 1320 & 5400 & 14 & 1133 \\
1 & 1.1 & 2027 & 0 & 1320 & 1884 & 0 & 1133 \\
Total & - & - & 1320 & - & - & 1133 & - \\
\hline
\end{tabular}

$H$ is height of the floor, $W$ is weight of the floor, $Q$ is seismic weight, and $V$ is base shear.

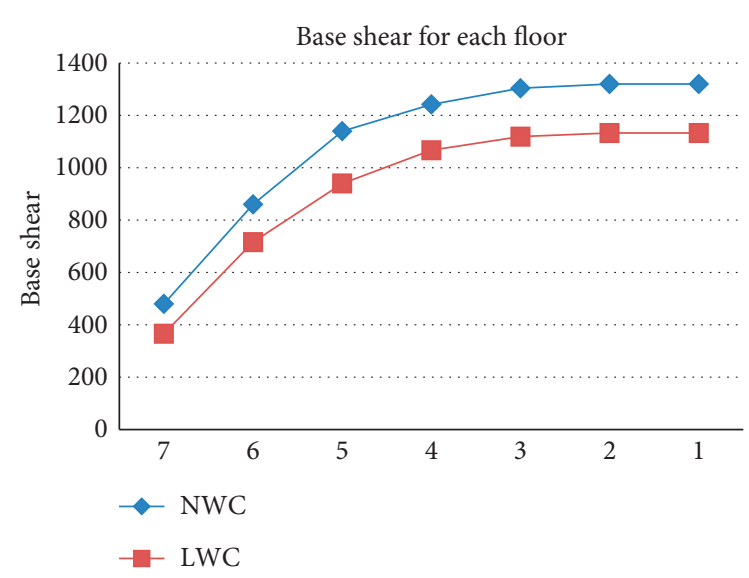

FIGURE 4: Base shear values of NWC and LWC for each floor.

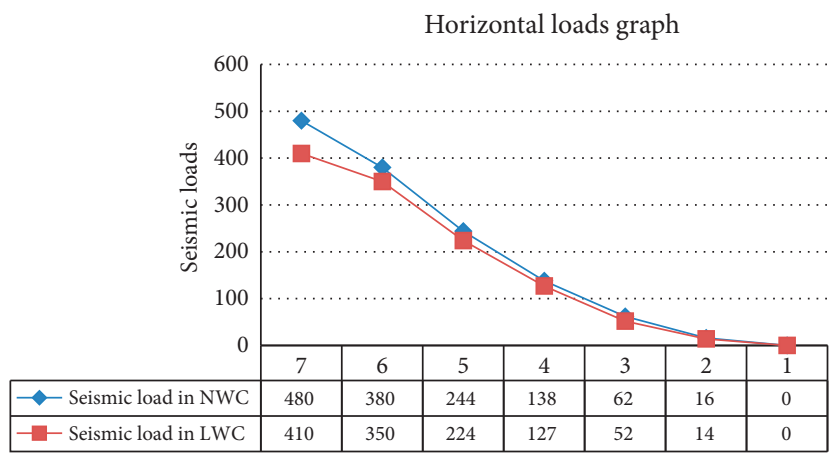

FIGURE 5: Horizontal loads of NWC and LWC for each floor.
TABLE 7: Normal weight concrete.

\begin{tabular}{lcc}
\hline Storey & Displacement $(\mathrm{mm})$ & Storey \\
\hline 7 & 56.1 & 3.6 \\
6 & 52.4 & 7.1 \\
5 & 45.27 & 10.1 \\
4 & 35.1 & 12.7 \\
3 & 22.4 & 14.1 \\
2 & 8.2 & 7.9 \\
1 & 0.35 & 0.35 \\
0 & 0 & 0 \\
\hline
\end{tabular}

TABLE 8: Lightweight concrete.

\begin{tabular}{lcc}
\hline Storey & Displacements $(\mathrm{mm})$ & Storey \\
\hline 7 & 61.05 & 3.6 \\
6 & 57.4 & 7.6 \\
5 & 49.7 & 11.0 \\
4 & 38.7 & 13.9 \\
3 & 24.8 & 15.6 \\
2 & 9.1 & 8.7 \\
1 & 0.39 & 0.39 \\
0 & 0 & 0 \\
\hline
\end{tabular}

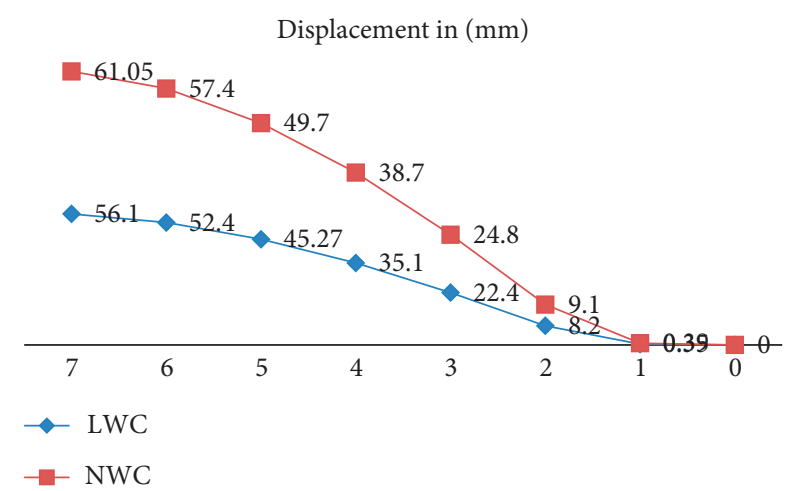

FIGURE 6: Displacements for each floor for both LWC and NWC structures.

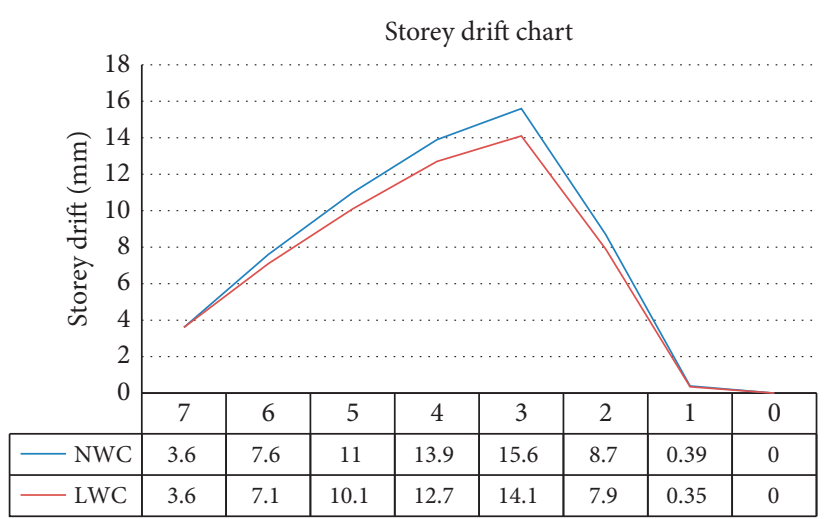

Figure 7: Storey drifts for each floor for both LWC and NWC structures. 
six-storied building shows the displacements and storey drifts of both lightweight concrete and normal weight concrete in Tables 7 and 8, and the variation in these for LWC and NWC is represented in Figures 6 and 7. Since the building configuration is the same in both the directions, the displacement values are the same in either direction.

The LWC structure suffers larger deformations than NWC because of lower Young's modulus of LWC, which results in lower stiffness; the obtained drifts from Table 8 are well within the allowable limits.

\section{Conclusion}

The seismic analysis of the structure is functionally depending on dead load and the earthquake forces acting on that. The LWC structure which is subjected to seismic analysis resulted in less bending moments and shear forces which may pave way either to reduce the cross section of members or to reduce the steel in moment and shear resisting sections. As the structure is six-storied, the change in earthquake forces is very little in both the cases, whereas storey drift and storey displacements are the same by this savage of steel, which is $10 \%$ more in LWC than NWC. The study was extended with dynamic analysis carried out using the response spectrum method. Though the natural period did not show any improvement for design considerations, the safety of the structure as observed from drift at each storey level is good. The reasons behind such changes are practically due to reduction of Young's modulus of lightweight concrete. However, with the new research, it is possible to get higher Young's modulus for the same strength parameters by suitable modification of concrete mix design. As the storey height increases, the benefit on economical is likely to be more.

\section{Conflicts of Interest}

The authors declare that there are no conflicts of interest.

\section{References}

[1] A. Kılıç, C. D. Atiş, E. Yaşar, and F. Özcan, "High strength lightweight concrete made with scoria aggregate containing mineral admixtures," Cement and Concrete Research, vol. 33, no. 3, pp. 1595-1599, 2003.

[2] ACI 211.2-98, "Standard practice for selecting proportions for structural lightweight concrete," 1998.

[3] A. Kan and R. Demirboga, "A novel material for lightweight concrete production," Cement and Concrete Composites, vol. 31, no. 7, pp. 489-495, 2009.

[4] Available Design Codes in STAAD Pro, pp. 1-14, Bentley Communities publisher, 2015.

[5] ACI 318-14, Building Code Requirements for Reinforced Concrete, vol. 552, American Concrete Institute, IHS, 2014.

[6] H. J. Shah, Design Example of a Six Storey Building. A Report by IIT Kharagpur-A Case Study.

[7] ASTM C 567, "Standard test method for determining density of structural lightweight concrete," 2014.

[8] ACI Committe-213, Guide for Structural LightweightAggregate Concrete, pp. 1-38, American Concrete Institute, Farmington Hills, MI, USA, 2003.
[9] IS 456-2000, Plain and Reinforced Concrete Code of Practice, Bureau of Indian Standards, New Delhi, India, 2000.

[10] Indian Standard: Earthquake Resistant Design and Construction of Buildings Code of Practice: 1893-2016, Indian code.

[11] A. Ulrik Nilsen, P. J. M. Monterio, and O. E. Gjørv, "Quality assessment of lightweight aggregate," Cement and Concrete Research, vol. 24, no. 8, pp. 1423-1427, 1994. 


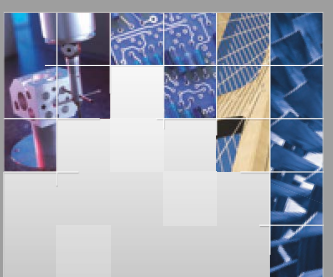

\section{Enfincering}
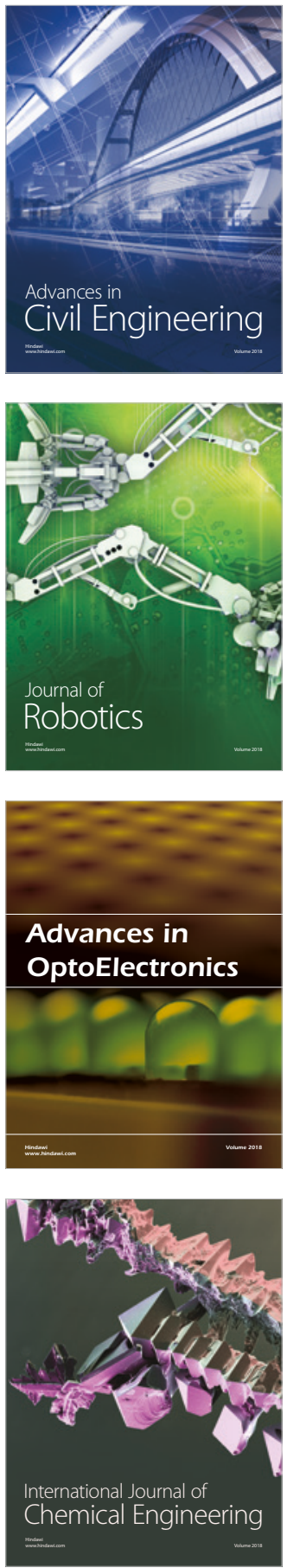

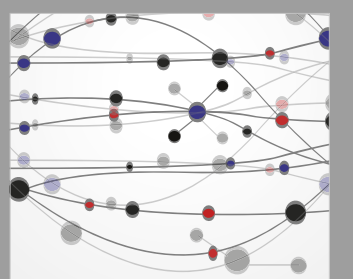

\section{Rotating \\ Machinery}

The Scientific World Journal

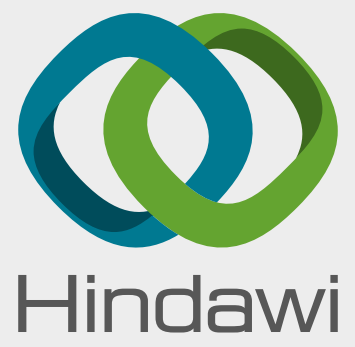

Submit your manuscripts at

www.hindawi.com
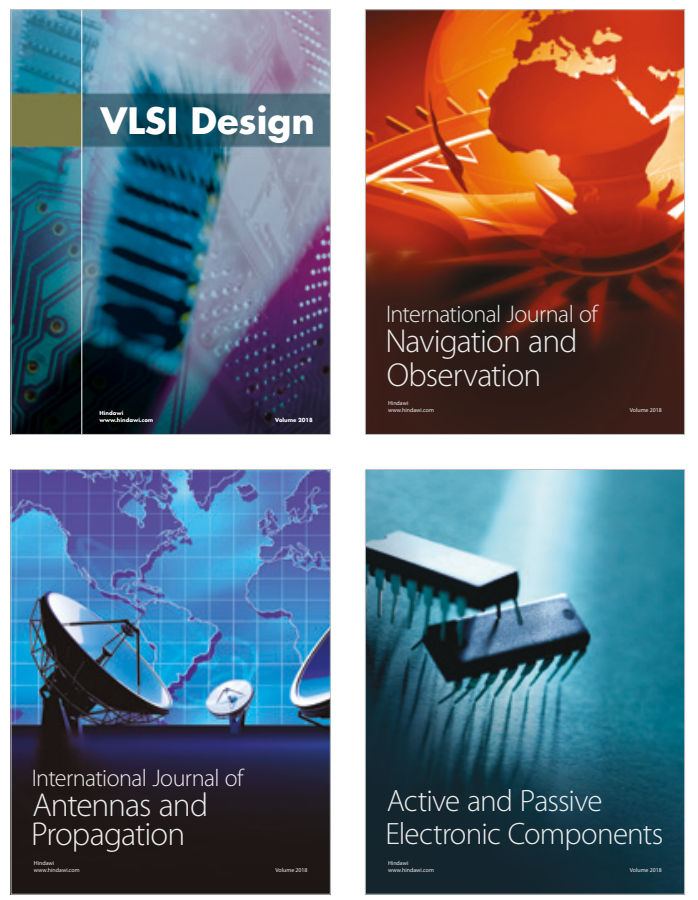
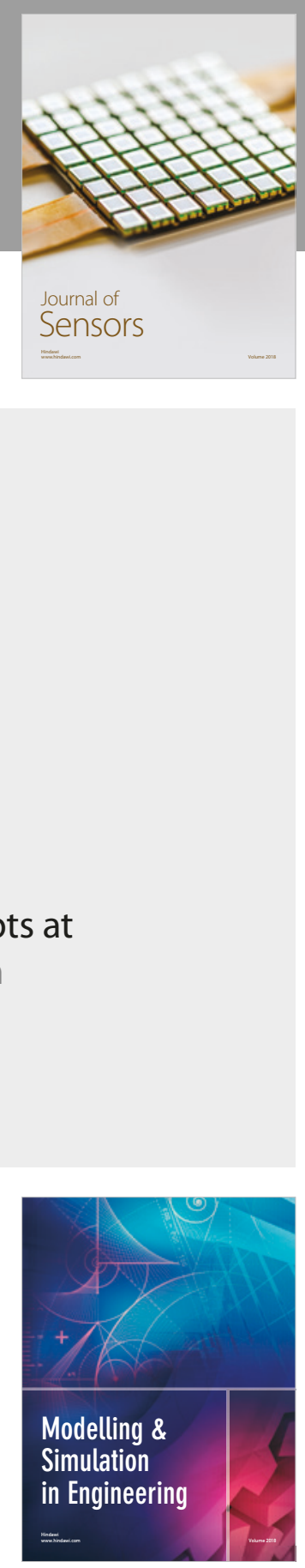

\section{Advances \\ Multimedia}
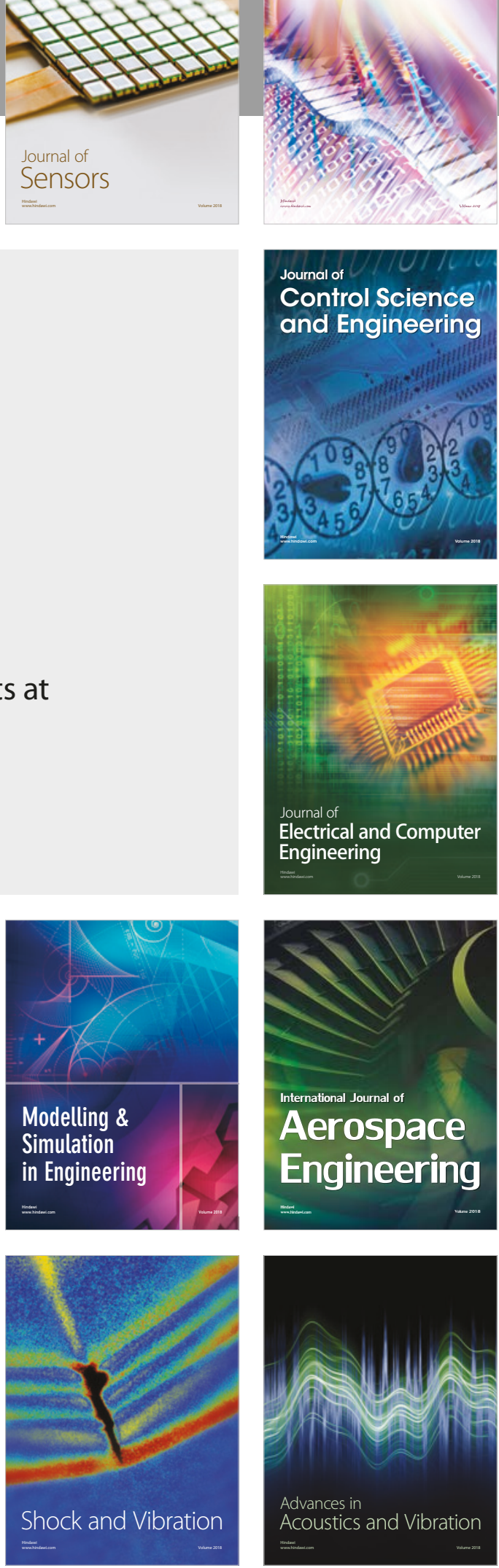